\title{
Publishing Theory and Praxis
}

\section{Information Literary, Theological Librarianship, and Atla Open Press}

Matthew Collins, Alma College

Kaeley McMahan, Wake Forest University

Bobby L. Smiley, Vanderbilt University

\begin{abstract}
The following contribution brings together three perspectives around the Atla Open Press book, Information Literary and Theological Librarianship: Theory and Praxis, published in 2019. Beginning with reflections from the book's editor (Bobby Smiley), these remarks also offer commentary from other panelists, who provide a background summary from the publisher's editor-in-chief (Matthew Collins), as well a case study that served as the basis for one the chapters in the volume (Kaeley McMahan).
\end{abstract}

\section{A PROLEGOMENA TO ANY FUTURE DISCUSSION OF THEOLOGICAL LIBRARIANSHIP AND INFORMATION LITERACY}

Bobby Smiley

Potter Stewart's oft-cited, now (in)famous apothegm from his opinion on Jacobellis v. Ohio (1964) - I know it when I see it-arguably applies to the work we do as theological librarians. While recognizing what uniquely separates our work from peers in other areas of academic librarianship, I frequently find it difficult to articulate (at least, articulate coherently) how that work is unique and, in my explanations, usually settle on identifying parallel domains to account for difference: institutional settings, instruction, constituencies, content knowledge, professional trends. What I've come to realize is that this toggling between theological and other forms of librarianship has provided sites of generative tension that have encouraged critical reflection, reimagination, and experimentation in our own library practice. Information Literacy and Theological Librarianship: Theory \& Praxis, I believe, has acted as one of those sites. Traversing multiple settings, constituencies, and trends in 
information literacy (IL), the volume's contributors have advanced arguments that engage in conversation outside of our own field while drawing their case studies, or theoretical explorations, back to the unique concerns or issues of theological and religious studies librarianship. Like the microhistorian who finds multum in parvo, the librarians who contributed to Information Literacy and Theological Librarianship provide an aperture into the work we do that simultaneously moves between our uniqueness and the broader concerns of academic librarianship.

I confess this is only a belated realization, and the genesis of this book owes much to those broader concerns. In my past work and research as a history and digital humanities librarian, I focused on questions of information literacy and disciplinary knowledge, and how to place the two in productive dialogue. I wanted to explore what library instruction can uniquely provide through the disciplinary language and threshold concepts of a particular field-history, biology, engineering, or indeed religion. Whether after or between sessions at Atla or over drinks following, I discussed with colleagues and friends about how (or if) they leveraged disciplinary affordances in their own information literacy instruction or used IL concepts to help teach disciplinary ones. And it was over afternoon beers during one of these conversations at the annual conference in 2018 that the idea for Information Literacy and Theological Librarianship was hatched.

In his capacity as the newly installed editor-in-chief of Atla Open Press, Matthew Collins suggested I consider pitching a volume on information literacy and theological librarianship to the press. As far as we both knew then (and still know now), there was no singleauthored or multi-authored edited monograph covering the subject and, even if there was, much had changed since the advent of the ACRL Framework in 2014 and the days when "bibliographic instruction" wasn't considered an epithet. (As a partisan of the term "information literacy," I also confess part of my motivation was unsubtlely to coax folks away from invoking "BI" to using "IL" and, in that rebranding, thereby have them reconsider and reflect on the whole enterprise of library instruction.) In subsequent conversations, we discussed wanting to draw contributors from a broad range of institutions and practices of IL librarianship, which I feel we largely satisfied. I wanted the volume to both speak to contemporary concerns as well as offer more perdurable ones, which I also feel we largely 
satisfied. To be sure, Information Literacy and Theological Librarianship has gaps and silences that should be acknowledged and named-tackling questions related to White supremacy, gender equity, and sexual expression, resource disparities, climate change and justice, among many others-lapses that apply to both content and contributors. I can only hope this will be redressed in future discussions, inasmuch as I believe theological and religious studies librarianship can and should bring its unique perspective on these concerns through how we conceive and enact information literacy instruction. That Information Literacy and Theological Librarianship can give librarians working in our diverse contexts and varied constituencies an opening gambit for stoking dialogue and reflection now and provide fodder (or even a template) for future volumes on similar topics motivated me throughout the entire process and demonstrates what we can (and will) bring to larger conversations about information literacy.

\section{THEORY AND PRAXIS}

Matthew Collins

The genesis of the volume Information Literacy in Religious and Theological Studies: Theory and Praxis was the 2018 Atla Annual in Indianapolis. Several presentations at the conference focused on the ACRL Framework and information literacy instruction in religious and theological studies. There was considerable discussion at the conference on this topic. The question of how and where the Framework was in use in the Atla constituency emerged from these discussions. After some consultation, the editorial board of Books@Atla Open Press invited Bobby Smiley to submit a proposal for a volume of essays, followed by a larger call for chapter proposals.

As the book came together, the editorial board and Atla investigated and then implemented a new software solution, Editoria, for manuscript editing and review. The Information Literacy volume was the first project produced in Editoria. The process of using this software, coupled with the PKP Open Monograph Press system already in use, resulted in a redefined editorial workflow for the larger Books@ Atla Open Press project. The new workflow is documented at atla. libguides.com/atlaopenpress/books. Atla now uses this workflow process for all volumes produced at Books@Atla Open Press. 


\section{SCHOLARSHIP AS CONVERSATION}

Kaeley McMahan

I shared a summary of my contribution to Information Literacy and Theological Librarianship: Theory and Praxis, "Scholarship as Conversation: Teaching an Information Literacy Course in a Divinity School Curriculum.” After reviewing several differences between the Information Literacy Competency Standards and the ACRL Framework for Information Literacy in Higher Education, I highlighted a few reasons why I specifically center the "Scholarship as Conversation" frame in my course, including that it:

- highlights the importance of proper citation practices and the understanding of what plagiarism is,

- acknowledges the variety of source types that are appropriate for research, beyond the traditional book and journal article,

- affirms that there may not be one right answer for every question, and that perspectives in a given discipline change over time.

The bulk of the summary covered the readings, in-class exercises and discussions, and assignments that help to incorporate the ideas of the "Scholarship as Conversation" frame into the course.

Readings came from selected chapters of $A$ Manual for Writers of Research Papers, Theses, and Dissertations, 9th ed. (Turabian 2018) and Melissa Browning's chapter, "Reading Basically," from Reading Theologically, edited by Eric Barreto (2014). Each of the frames was reflected at some point in the course readings.

"Plagiarism, Privilege, and the State of Christian Publishing" by Emily C. Heath (2017) was the focus for one course discussion, which gave a real-world example of a pastor whose previous work was plagiarized by a well-known minister. Heath's reflection allowed the students to discuss several aspects of the Framework within the context of a very relatable experience.

The Specialized Scholarly Journal Article Assignment gave the students the opportunity to investigate one of several journal resources that they are not usually allowed to use for research papers, but which are important sources of information if they pursue PhDs or DMins: book or literature reviews, an in-depth interview with a scholar, scholarly responses/conversations via articles, a theme issue of a journal. I shared the experience of one of my students, 
who found a scholarly response article for her assignment. She later attended AAR-SBL as a student and introduced herself to the author of the article after one of the scholar's presentations. To me, this was a good indication that the student had absorbed the knowledge practices and dispositions of the "Scholarship as Conversation" frame.

The full course syllabus, assignments, reading list, and other material, along with my portion of the 2020 conference presentation PowerPoint, can be found at: tinyurl.com/y9y4bt28. The book chapter can be found at: books.atla.com/atlapress/catalog/view/33/36/204-1.

\section{Works Cited}

Browning, Melissa. 2014. "Reading Basically.” In Reading Theologically, edited by Eric Barreto, 15-29. Minneapolis: Fortress Press. Heath, Emily C. 2017. "Plagiarism, Privilege, and the State of Christian Publishing." Ministry Matters, September 11, 2017. www. ministrymatters.com/all/entry/8410/plagiarism-privilege-andthe-state-of-christian-publishing.

Turabian, Kate L. 2018. A Manual for Writers of Research Papers, Theses, and Dissertations. Ninth edition. Chicago: University of Chicago Press. 